\title{
Dyskryminacja, akceptacja i niewidzialność nauczycielek nieheteronormatywnych na przykładzie wypowiedzi nauczycielek pracujących w kilku polskich szkołach
}

\begin{abstract}
The article is an analyze of non-heteronormative female teachers experience of their work place. It shows both their personal experience of exclusion (or inclusion) and understanding of that experience. Results are based on qualitative research (life-history interviews) with 8 teachers, analyze of internet phorum and also comparison with other European and American data. There are not a lot of research about such topic, not just in Poland but also in other countries, most of the European articles on this topic is based on qualitative research with few teachers. Results of such research should be presented and also should be an inspiration to other wider analyzes. Results of the research show that the majority of responders has never came out in their work place. They were afraid of discrimination and homophobia. The fear which was the reason of keeping in secret the information about sexual orientation was presented mainly among the teachers who were working in villages and small towns. Just on of my responders hasn't ever heard any homophobic jokes or comments in her workplace.
\end{abstract}

1 Marcela Kościańczuk, Zakład Semiotyki Kultury, Instytut Kulturoznawstwa, Wydział Nauk Społecznych, Uniwersytet im. Adama Mickiewicza w Poznaniu, Polska, marcelak@amu.edu.pl. 
A lot of teachers indicated that 'being in the closet' is not comfortable for them because they have to hide a lot of information connected with their daily life and it separates them from the group of collegues. Most of them have founf one or two collegues and told them about their secret. Most of non-heteronormative teachers have good relations with pupils and these teachers connect their open attitude toward pupils problems with their personal experience of exclusion.

\section{Key words:}

homophobia, school system, female non-heteronormative teachers, coming out at school

\section{WSTĘP}

Inspiracją dla podjęcia tematu sytuacji nieheteroseksualnych nauczycielek było bardzo obecne w mediach wystąpienie jednej z nich, która dziś już nie jest nauczycielką, ale dziennikarką i publicystką. W 2010 roku Marta Konarzewska ujawniła, że była dyskryminowana z powodu swojej orientacji seksualnej, gdy pracowała w jednym z łódzkich liceów. Wywiad z nią został opublikowany w „Gazecie Wyborczej” (Konarzewska, 2010), wywołał kontrowersje, a sama bohaterka szybko zyskała nową pracę. W ślad za znaną dziś publicystką nie poszły jednak inne kobiety nieheteronormatywne pracujące w polskich szkołach. Wyznanie Konarzewskiej nie stało się początkiem coming outów (ujawnień) nauczycielek nieheteroseksualnych. Temat nauczycielek lesbijek pojawiał się w dyskursie społecznym przy zupełnie innych okazjach, m.in. w kontekście wypowiedzi Elżbiety Radziszewskiej, byłej przedstawicielki rządu ds. równego traktowania kobiet i mężczyzn, która przedstawiła interpretację dyrektyw unijnych, w świetle której szkoła katolicka może odmówić zatrudnienia osobom nieheteroseksualnym (Radziszewska, 2010).

Nie tylko problematyka homoseksualnych pedagogów nie jest podejmowana w polskim dyskursie naukowym, ale także sam temat kobiet homoseksualnych jest dość rzadko przedmiotem badań naukowych. W Polsce istnieje niezbyt szeroka literatura dotycząca sytuacji kobiet nieheteronormatywnych w życiu społeczno-politycznym, jednakże istnieje kilka ważnych pozycji wydanych przez polskich badaczy i badaczki. Joanna Mizielińska (2006) zarówno zajmuje się wprowadzaniem tematyki dyskryminacji osób nieheternormatywnych do polskiego dyskursu kultu- 
rowego, jak i prowadzi szerokie badania nad zagadnieniem związków pomiędzy orientacją seksualną a postrzeganiem własnej sytuacji rodzinnej. Marzena Chińcz (2006) wydała książkę dotyczącą sytuacji społeczno-politycznej lesbijek w oparciu o warsztaty i spotkania z homoseksualnymi kobietami, Małgorzata Kotowska (2011) opracowuje publikacje na podstawie zebranych doniesień o dyskryminacji osób homo- i biseksualnych, a Jacek Kochanowski (2007) opisuje ruchy społeczne kobiet i mężczyzn homoseksualnych. Warto także wspomnieć teksty Błażeja Warkockiego (2004, 2013), redaktora i autora książek poświęconych analizie zjawiska homofobii, dotyczące sytuacji zarówno mężczyzn, jak i homoseksualnych kobiet.

W Polskiej literaturze przedmiotu nie ma pozycji traktujących o dyskryminacji homoseksualnych nauczycielek, jednakże pewne elementy analizy sytuacji wykluczenia i mobbingu, wynikającego z przynależności do grupy mniejszościowej, można odnaleźć w tekstach opublikowanych przez Jarosława Marciniaka (2011), Agatę Lankamer i Patrycję Potocką-Szmoń (2006), Witolda Klausa i Aleksandrę Winiarską (2011, s. 9-40). Ta ostatnia pozycja wskazuje, w jaki sposób dyskryminacja wypływa z nietolerancji, rozróżnia także dyskryminację bezpośrednią, utrwalającą przywileje dla określonej - najczęściej większościowej - grupy społecznej w sposób jawny i zamierzony, i dyskryminację pośrednią, która nie musi być całkowicie zamierzona, ale jest efektem wcześniejszych dyskryminacyjnych działań. Wiele nauczycielek biorących udział w badaniach jest nieujawnionych w swoich miejscach pracy, ale ze względu na docinki i żarty dotyczące osób homoseksualnych doświadczają one w sposób pośredni dyskryminacji. Ważnymi pozycjami na rynku polskim dotyczącymi tematyki łamania praw osób homoseksualnych są raporty Kampanii Przeciw Homofobii, która zbadała sytuację homoseksualnej młodzieży w szkołach (Świerszcz, 2012), a także praca zbiorowa: Przełamać milczenie: łamanie praw człowieka ze względu na orientację seksualnq (Maruszewski i in., 2003). Wszystkie wskazane pozycje są analizami zjawisk dyskryminacji, w dwóch ostatnich przypadkach skupionymi szczegółowo na homofobii, nie dotyczą one jednak dyskryminacji grona pedagogicznego o orientacji homoseksualnej.

Być może brak literatury związanej z tym tematem wynika z faktu, że badania przeprowadzane na grupie nieheteroseksualnych nauczycielek są rzadkie i trudne, nie tylko w polskim kontekście. Analiza zagranicznych publikacji pokazuje, że temat ten jest wciąż niezbadany i trudny do analizy (ze względu na nieujawnienie większości respondentek i ich lęk przed wypowiedziami na ten temat). Artykuły powstające na ten temat są najczęściej studiami przypadków bądź też opierają się na kilku doświadczeniach kobiet, które zdecydowały się podzielić swoją historią doświadczeń nauczycielki, której orientacja seksualna może być przyczyną dyskryminacji (Sparkes, 1994; Hardie, 2012; Rudoe, 2010). Jedynym większym 
badaniem, przeprowadzonym w USA (ilościowym, na grupie 868 nauczycieli i nauczycielek nieheteronormatywnych), było porównanie strategii radzenia sobie ze stresem i wypaleniem zawodowym wśród nauczycieli zrzeszonych w organizacjach nauczycieli gejów i lesbijek (z której pochodziło około 600 badanych) i osób niezrzeszonych (Juul, 1996). W Polsce nie ma ani jednej organizacji wspierającej nauczycieli czy nauczycielki nieheteroseksualne.

Również badania, którego wyniki przedstawione zostaną w tym artykule, nie można nazwać reprezentatywnym. Dotarcie do grupy ośmiu kobiet, które zgodziły się opowiedzieć o swoich doświadczeniach, zajęło około dwóch lat i było związane niejednokrotnie $\mathrm{z}$ wieloma negocjacjami i zapewnieniami o anonimowości wypowiedzi, a niejednokrotnie także zaufaniem zbudowanym przez dłuższy kontakt z osobami badanymi. Metodą był wywiad pogłębiony, częściowo ustrukturalizowany (dający możliwość poszerzenia odpowiedzi na główne pytania badawcze). Głównymi problemami badawczymi były następujące kwestie:

1. Strategie przyjmowane przez nauczycielki nieheteronormatywne w ich miejscach pracy, dotyczące ujawnienia bądź zatajenia własnej orientacji seksualnej, a także co często jest z tym związane pewnych szczegółów z życia osobistego.

2. Problematyka doświadczania bezpośredniej lub pośredniej dyskryminacji w miejscu pracy.

3. Wpływ orientacji seksualnej na relacje i pozycję w miejscu pracy.

4. Subiektywne obawy i wyobrażenia kobiet nieheteronormatywnych będących nauczycielkami dotyczące ich zawodu.

Do badania zaproszono nauczycielki uczące osoby niepełnoletnie na wszystkich szczeblach edukacji (od edukacji przedszkolnej do szkoły średniej). Osoby biorące udział w badaniu pochodzą z różnych regionów Polski (dwie reprezentują Polskę zachodnią, dwie wschodnie województwa, a cztery centrum Polski). Brałam też pod uwagę doświadczenia kobiet, które obecnie nie są już nauczycielkami, także ze względu na trudność w połączeniu własnej identyfikacji i zawodu nauczyciela. Jedna osoba opowiadała o swoich doświadczeniach jako początkująca nauczycielka (z bardzo krótkim, kilkumiesięcznym stażem pracy), natomiast pozostałe respondentki wskazywały, że ich staż pracy wynosi od pięciu do kilkunastu lat w zawodzie nauczyciela. Dwie nauczycielki wskazywały na pracę w jednostkach niepublicznych (w tym jedna w szkole katolickiej, a druga w prywatnym przedszkolu), pozostałe respondentki były nauczycielkami w szkołach publicznych, w tym dwie osoby pracujące w szkolnictwie specjalnym. Cztery kobiety uczą w miastach zamieszkiwanych przez kilkaset tysięcy mieszkańców, pozostałe dwie w mniejszych miejscowościach (poniżej 40000 mieszkańców) i dwie uczą 
w szkołach na terenach wiejskich. Dodatkowym uzupełniającym źródłem była analiza forum internetowego na stronie kobiety-kobietom.com (portal dla kobiet nieheteronormatywnych). Uczestnictwo w forum trwało trzy miesiące. Jednakże ze względu na brak dużej aktywności kobiet informacje z forum internetowego zostały potraktowane jedynie jako dodatkowe, uzupełniające źródło danych, a głównym źródłem są pogłębione wywiady z respondentkami. Dla porównania sytuacji polskich nauczycielek i nieheteronormatywnych przedstawicielek tego zawodu z innych krajów podaję kilkukrotnie odwołania do wywiadów opublikowanych przez zagranicznych badaczy (A.C. Sparks, A. Hardie).

\section{STRATEGIE ZWIAZZANE Z UJAWNIANIEM LUB UKRYWANIEM SWOJEGO ŻYCIA PRYWATNEGO}

Jedynie dwie spośród ośmiu moich respondentek ujawniły otwarcie w swoich szkołach, że są osobami nieheteronormatywnymi. Faktycznie jednak nawet one wskazywały, że sytuacja coming outów nauczycielek nieheteronormatywnych jest w Polsce zupełnym ewenementem. Moje rozmówczynie, które ujawniły swoją orientację w miejscu pracy, wskazywały, że „mają wyjątkowe szczęście” (R7 ujawniona nauczycielka z dużej miejscowości), czy też, że szkoła, w której uczą, jest bardzo specyficzna (R4 ujawniona nauczycielka z dużej miejscowości)². Wszystkie respondentki, które ze mną rozmawiały, znały jeszcze przynajmniej kilka nauczycielek nieheteronormatywnych (które pracują w okolicznych szkołach), ale próby zaproszenia ich do anonimowego wywiadu pozostały nieudane. Kobiety te tak bardzo bały się ujawnienia swojej orientacji, że pomimo zapewnień o anonimowości badań, a także możliwość wglądu w treść zacytowanych wypowiedzi przed ich publikacją, nie przekonały się do zaufania i ujawnienia swoich doświadczeń. Świadczy to o ogromnym poczuciu zastraszenia nauczycielek o orientacji nieheteroseksualnej. Można wnioskować, że fakt, iż dwie spośród moich rozmówczyń były osobami ujawnionymi w swoim miejscu pracy, nie daje możliwości wnioskowania, iż każde dwie na osiem nauczycielek dokonuje coming outu w swoich placówkach. Przeciwnie, wydaje się raczej, że respondentki te ze względu na to, że nie utrzymują tajemnicy dotyczącej swojej orientacji, z większą łatwością wzięły udział w badaniach. Natomiast ich koleżanki już nie miały tej śmiałości.

2 Dla zachowania wymogów anonimowości respondentki zostały określone oznaczeniami R1 (respondentka nr 1)-R8 (respondentka nr 8). 
Ukrywanie orientacji seksualnej przez moje respondentki wiązało się nie tylko i nie tyle z nieujawnianiem informacji dotyczących sfery ściśle intymnych. Rozmówczynie wskazywały, że samo określenie orientacji seksualnej nasuwa ludziom skojarzenia ze sferą seksu, która dla moich rozmówczyń była przestrzenią intymną, jednakże ich orientacja seksualna wpływała na to, że model rodziny, w którym żyły, czy też wiele aspektów ich życia codziennego było związane z relacją z drugą kobietą. Zachowanie w tajemnicy informacji o własnej orientacji seksualnej było dla kobiet żyjących w związkach, powiązane z niemożnością ujawnienia bardzo wielu aspektów z życia prywatnego.

Niekiedy kobiety te traktowane były jako słabe jednostki, którym nie udało się znaleźć męża. Jedna z respondentek opowiadała:

Dla mnie bardzo stresujqce sq takie sytuacje, gdy ludzie mnie pytajq, a kiedy wychodzisz za mąż, a czy masz chłopaka? Miałam też jednq koleżankę, która chciała mnie na siłę swatać z jakimś swoim kolega, ja się przed tym broniłam rękoma i nogami, dopiero inna koleżanka powiedziała jej trochę do słuchu...To sq tego typu sytuacje. Ja zazwyczaj zbywam to jakimś żartem i się odczepiajq. (R5 nieujawniona respondentka, pracująca na wsi)

Inna spośród moich respondentek także porusza temat „swatania”:

Wszystkie próby swatania były dla mnie trudne. Mówiły, że ta ma kuzyna albo a taki miły pan się wprowadził. Byłam tym bardzo zmęczona. Na poczq̨tku żartami to zbywałam, ale później byłam na tyle zmęczona i sfrustrowana, że nie wiedziałam zupełnie jak mam się w tym odnaleźć, nie umiałam powiedzieć nie, ale oczywiście nie chciałam też niczego takiego. Byłam tym okropnie zmęczona. ( R8 była nauczycielka, pracująca na wsi, nieujawniona)

Wiele rozmów, które toczą się w czasie przerw i spotkań towarzyskich między nauczycielkami, dotyczy spraw rodzinnych, relacji damsko-męskich, spraw związanych z mężami czy partnerami życiowymi. Kobiety, które milczą, nie dzielą się swoimi doświadczeniami, są uważane za samotne, co może być wiązane z nieporadnością bądź brakiem szczęścia w relacjach damsko-męskich. Dla większości moich rozmówczyń tego typu codzienne rozmowy są źródłem stresu, podczas gdy dla innych kobiet są to momenty dające chwilę relaksu i budowania bliższych więzi z koleżankami z pracy.

Niektóre osoby nieheteronormatywne wybierają inny sposób dzielenia się informacjami o swoim życiu, stosują grę narracyjną, określając swoje partnerki mianem 
partnerów. Taką drogę wybrała jedna z moich rozmówczyń, która zmieniła imię partnerki na imię męskie (R3 nauczycielka z krótkim stażem pracy, nieujawniona, z dużej miejscowości) i bez skrupułów opowiadała o swoim życiu prywatnym. Jak jednak wskazuje jedna z użytkowniczek forum dla lesbijek, gdzie również toczyła się dyskusja na temat połączenia zawodu nauczycielki z nieheteronormatywną orientacja i ten sposób zdobywania bliższych relacji z gronem pedagogicznym nie jest zupełnie pozbawiony problemów i stresu:

W pokoju nauczycielskim toczq się całkiem niewinne (z pozoru) rozmowy, ale nie jest łatwo lawirować między końcówkami czasowników i zaimkami, w końcu albo popadasz w nerwicę, albo milkniesz zupełnie (Użytkowniczka o pseudonimie Pansy) ${ }^{3}$.

Respondentki pracujące w szkołach wiejskich i tych znajdujących się w małych miastach częściej wskazywały na to, że głównymi tematami rozmów w pokoju nauczycielskim były sprawy ściśle prywatne, rodzinne. Tam też o wiele trudniej byłoby udawać związek z nieistniejącym chłopakiem czy mężem. Jak wynika z opowieści moich rozmówczyń, w małych szkołach grono pedagogów utrzymuje bardzo zażyłe, przyjacielskie relacje. Niejednokrotnie organizowane są dodatkowe półsłużbowe spotkania, wyjazdy do teatru, wycieczki czy pikniki, na które zapraszane są także rodziny nauczycielek. Te wszystkie półprywatne, a półsłużbowe wydarzenia były bardzo trudne dla respondentek nieujawniających swojej orientacji seksualnej.

Moje rozmówczynie wskazywały, że w relacjach z koleżankami z pracy oraz dyrekcją towarzyszy im niejednokrotnie strach, zdenerwowanie, wstyd. Żyję w ciqgłym strachu, w pracy nie jestem w pełni sobq, kontroluję swoje wypowiedzi (R1 nauczycielka nieujawniona z dużej miejscowości); Nie wiem, czy aż tak się boję, ale sq stresujq̨ce sytuacje (R5 nauczycielka pracująca w średniej miejscowości, nieujawniona); Trudny był dla mnie czas ukrywania, że moja dobra koleżanka, o której zaczęły krążyć plotki, że jest lesbijkq, wcale nie jest mojq koleżankq (R6 nauczycielka pracująca na wsi, nieujawniona); Bałam się (R3 nauczycielka z krótkim stażem, z dużej miejscowości, nieujawniona).

By w jakiś sposób przełamać izolację i brak relacji z innymi nauczycielkami, kobiety często odnajdują jakąś przyjazną osobę, przed którą decydują się ujawnić. Wcześniej jednak przygotowują się do tego, sprawdzają, czy jest to możliwe, czy wybrana koleżanka jest na tyle otwartą osobą, że będzie w stanie zaakceptować

3 http://kobiety-kobietom.com/forum/viewtopic.php?p=195495 
mniejszościową orientację. Niektóre rozmówczynie domyślają się, że wśród ich współpracowniczek są osoby, które także nie są heteroseksualne. Niejednokrotnie to właśnie one stają się ich powierniczkami. Kobiety, szanując wybór koleżanki, nie wypytują ją o orientację, ale same ujawniają się przed osobą, o której myślą, że jest podobnej do nich orientacji. Częściej jednak powierniczką staje się osoba heteroseksualna, która jest akceptująca, ma zbliżone poglądy oraz nie włącza się aktywnie w homofobiczne żarty w szkole.

Kobiety wskazywały, że przyjaźń z zaufaną heteroseksualną koleżanką jest dla nich źródłem większego poczucia bezpieczeństwa oraz możliwością zbudowania relacji przynajmniej z jedną osobą z grona pedagogicznego. Kobiety te traktują osoby, które wiedzą o ich orientacji, jako potencjalne źródło wsparcia w trudnych sytuacjach, gdyby groziły im szykany ze względu na orientację seksualną. Jedna z kobiet (R7 ujawniona nauczycielka, z dużej miejscowości), która w dość dramatyczny sposób ${ }^{4}$ ujawniła swoją orientację seksualną niemal całemu gronu pedagogicznemu (poczynając od dyrekcji), mówiła o tym, że odnajduje teraz duże wsparcie w osobie dyrektora, który (zapewne także ze względu na swoją pozycję służbową) skutecznie ucisza wszelkie spekulacje w pokoju nauczycielskim. Z drugiej jednak strony dyrektorowie namawiają respondentkę do większego umiaru w ujawnianiu swojej orientacji. Kobieta mówi: Mówiłam dyrektorce, że ja też chciałabym chodzić za rękę z mojq partnerkq, a ona mi mówi, to nie chodźcie za rękę, ale pod rękę. Ona ma w sobie wiele strachu. (R7 ujawniona nauczycielka, z dużej miejscowośći)

Jedna z respondentek (R2 nauczycielka z krótkim stażem, z dużej miejscowości) wskazywała, że fakt, iż dyrekcja jej szkoły oraz kilka nauczycielek wiedzą o jej orientacji seksualnej, nie daje jej pełni poczucia bezpieczeństwa, ale raczej determinuje do tego, by ściślej kontrolowała swoje zachowanie.

Uczestniczki internetowej debaty na temat swoich doświadczeń jako lesbijki i nauczycielki również mówiły o tym, że ich pracodawcy wiedzą o ich orientacji, ale zarazem chcą (w przekonaniu uczestniczek forum), by nie dokonywały coming outu (Ja lubię, to co robię. I boję się bardzo. Ale... zaufane współpracowniczki wiedzq, a z Paniq Dyrektor mam nie pisany układ o nieporuszaniu tego tematu [Użytkowniczka o pseudonimie Szczurzyca]) $)^{5}$.

Okazuje się zatem, że nawet sytuacja ujawnienia swojej orientacji oraz co często jest z tym związane - pewnych elementów z życia prywatnego nie zawsze stanowi dla badanych kobiet możliwości dalszego rozwoju i spokojniejszego

\footnotetext{
4 W odpowiedzi na wielokrotne skargi na nią kierowane do dyrektora przez katechetę.

5 http://kobiety-kobietom.com/forum/viewtopic.php?p=195495
} 
współistnienia ze współpracownikami. Osoby, które dowiadują się o orientacji nauczycielki, stanowią pewnego rodzaju wsparcie dla tej kobiety, z drugiej jednak strony niejednokrotnie przenoszą na nie swoje lęki i własne przekonanie o tym, że informacje na ten temat powinny być zachowywane w tajemnicy.

Z rozmów wynika, że żadna z kobiet właściwie nie chciałaby żyć w ukryciu, gdyby sytuacja była dla nich sprzyjająca, gdyby znalazły się w akceptującym środowisku, gdyby nie były narażone na szykany czy docinki lub wręcz groźbę zwolnienia z pracy, wolałyby ujawnić swoją orientację i móc uczestniczyć w większej mierze w relacjach społecznych w swoich środowiskach pracy. Jedna z moich respondentek która ujawniła swoją orientację w odpowiedzi na próby dyskredytowania jej osoby przez katechetę, stwierdziła, że była to forma wyrażenia własnej frustracji, Uważała, że w tamtej sytuacji nie ma innego wyjścia, a coming out był formą obrony. Podjęcie tego rodzaju aktu przyniosło jednak bardzo dobry rezultat. W wywiadzie mówiła: nie czuję już strachu. Miałam szczęście, dobrze trafiłam, gdybym teraz miała zmienić pracę, wróciłby ten strach (R7 ujawniona nauczycielka z dużej miejscowości).

Inna respondentka właściwie nieco obwiniała się, że nie zaryzykowała ujawnienia swojej orientacji, mówiła: być może sama sobie te bariery ułożyłam w głowie, nigdy nie sprawdziłam ich reakcji. Może była to moja własna blokada. (R8 była nauczycielka z dziesięcioletnim stażem, pracująca na wsi). Wcześniej jednak ta sama respondentka wskazywała, że każdego dnia ktoś z grona pedagogicznego przynosił do pokoju nauczycielskiego nowe homofobiczne żarty, a wszelka inność w jej otoczeniu była negowana. Osoby, które dokonywały niestandardowych (na miarę tego środowiska) wyborów życiowych (do których należał np. ślub z obcokrajowcem), były dyskryminowane i izolowane. Trudno zatem domniemywać, że strach respondentki przed ujawnieniem swojej orientacji był bezpodstawny. Kobieta wskazywała, że gdyby grono pedagogiczne dowiedziało się o jej życiu prywatnym, prawdopodobnie szykanowałoby ją tak, że ostatecznie sama zrezygnowałaby z pracy. Obecnie od kilku lat kobieta ta nie pracuje w szkolnictwie. Zrezygnowała, jednakże miała okazje sama przygotować sobie zmianę pracy, nie była do tego bezpośrednio zmuszona przez szykany, jakich się obawiała. Faktem jest jednak, że homofobiczna atmosfera w miejscu pracy doprowadziła ją ostatecznie do rezygnacji, poprzedzonej ponad 10-letnim wysiłkiem ukrywania się. 


\section{WYMIARY WYKLUCZENIA}

Milcząca zgoda na społeczna niewidzialność, wyrażana pod presją lęku jest najczęstszą, przyjmowaną przez nieheteroseksualne nauczycielki strategią omijania wykluczenia i homofobicznych ataków. Niechęć do ujawniania jakichkolwiek szczegółów z życia prywatnego naraża je jednak na społeczny ostracyzm. Wywołuje także wrażenie, iż - jak pisała Marzena Lizurej w tekście Lesbijki ? Przecież nas nie ma (2004, s. 229-231) - kobiety te nie są akceptowane we wszystkich aspektach ich tożsamości. Kobiety nieheteronormatywne są niewidzialne, nierozpoznawalne w otoczeniu. Nie ujawniają się, ponieważ nie dostrzegają, że środowisko mogłoby je zaakceptować. Są niejako skazane na życie w ukryciu bądź zmianę otoczenia.

Podobna sytuacja nie dotyczy jedynie Polski. Podczas stażu w Wielkiej Brytanii miałam okazję rozmawiać na ten temat z kadrą Centrum międzydyscyplinarnych studiów nad płcią kulturową na Uniwersytecie w Leeds. Przyznali oni, że również w innych niż Polska krajach europejskich istnieje problem dyskryminacji i wykluczenia nieheteronormatywnych nauczycielek. Potwierdza to rozmówczyni Andrew C. Sparksa, badacza z Uniwersytetu w Exeter. Respondentka ta mówiła, że jedyne opinie, które słyszy na temat osób homoseksualnych, to negatywne zdania, powtarzanie stereotypów i krzywdzących ocen. Kobieta także wypowiedziała słowa zbieżne z opiniami wielu moich rozmówczyń:

Czuję się niewidzialna. Nie tyle i nie tylko ze względu na mojq orientację seksualnq, ale dlatego, że nie mogę stworzyć żadnych społecznych relacji, że jestem wykluczona, niewidzialna, nikt nie ma pojęcia, kim naprawdę jestem (Sparkes, 1994, s. 93).

Kobiety, które bardzo bronią swojej prywatności i nikomu nie wspominają niczego na temat swojego życia, stają się niekiedy przedmiotem plotek uczniów, rodziców bądź innych nauczycieli. Najczęstszym tematem tych opowieści powtarzanych za plecami samych zainteresowanych jest oczywiście kwestia niezaradności kobiet, które nie umieją sobie znaleźć partnera; jednakże niektóre spośród kobiet nieheteroseksualnych nagle dowiadują się, że ktoś rozsiewa „pogłoski” o tym, iż prawdopodobnie są lesbijkami. Taka sytuacja zdarzyła się jednej z moich respondentek. Ujawniła ona swoją orientację jedynie dwóm osobom, spośród których jedna była także osobą nieheteronormatywną. Moja rozmówczyni opowiedziała tę sytuację: 
Niegdyś uczniowie podejrzewali moją koleżankę z pracy lesbijkę, a że kolegujemy się, to wymyślili w drugim życiu, że pewnie jesteśmy parq̨. Oficjalnie to nigdy nie dotarło, ale sugerowali to w komunikatach niewprost, szczególnie mojej koleżance, którq̨ to bardziej dotykało. Prawdopodobnie z tego powodu, aby trochę jej dokuczyć skoro działało (R6 nieujawniona nauczycielka z małej miejscowości).

Zdarzenie to było ogromnie trudne dla obu kobiet, które zdecydowały udawać, że niemal wcale się nie lubią, nie znają poza szkołą i są jedynie współpracowniczkami. Moja rozmówczyni wskazuje, że to był najtrudniejszy czas podczas jej pracy w szkole. Obie nauczycielki nie szukały i nie mogły znaleźć pomocy u innych osób z grona pedagogicznego, dążąc do tego, by nikt więcej nie zainteresował się rozsiewanymi przez uczniów plotkami. Kluczowa była reakcja obu kobiet na homofobiczne komentarze. Moja rozmówczyni zdawała sobie sprawę, że musi pokazywać (nawet wbrew prawdzie), że plotki jej nie dotykają, gdyż w innym wypadku jedynie pogorszyłaby swoją sytuację. Podobną strategię przyjęła rozmówczyni Ann Hardie, która robiła badania nad dyskryminacją nauczycielek nieheteronormatywnych w Nowej Zelandii. Respondentka uczyła w szkole podstawowej i pewnego razu nieświadoma niczego uczennica podeszła do niej, by poinformować ją o tym, że inni uczniowie mówią o niej „brzydkie rzeczy”. Nauczycielka skojarzyła to z własnym stylem ubierania i fryzurą i zdała sobie sprawę z tego, że prawdopodobnie chodzi o wyzwiska związane z orientacją seksualną (która jednak nie była znana uczniom). Kobieta szybko stanowczym tonem dała prosty komentarz (niektórzy nie majq o czym rozmawiać, czyż nie?) i szybko się oddaliła, by nie ukazać swych prawdziwych emocji (Hardie, 2012, s. 276).

Niestety, jednak nie wszystkie nieheteronormatywne nauczycielki mają tyle siły psychicznej i umiejętności trzymania emocji na wodzy. Jedna z kobiet, z którą rozmawiał badacz z Exeter, młoda nieheteronormatywna wychowawczyni wskazywała, że uczniowie wielokrotnie wystawiają ją na próbę, choć nie jest pewne, czy robią to z powodu domysłów dotyczących jej orientacji seksualnej. Jessica, jak autor nazywa tę rozmówczynię, opowiadała o tym, że jej mali uczniowie podczas nauki pisania i czytania wypytywali się jej, jak przeliterować słowo lesbijka (ibidem, s. 104). Kobieta czuła się dotknięta, choć zarazem zastanawiała się, czy ta prośba była związana z próbą dokuczenia jej, czy też może z odpowiedzią dzieci na brak w ich środowisku neutralnych komunikatów na temat mniejszości seksualnych. 


\section{RÓŻNE ROZUMIENIA I DOŚWIADCZENIA HOMOFOBII}

Wśród pytań, które zadawałam moim rozmówczyniom, było również takie, które dotykało wprost kwestii homofobii. Pytałam o to, czy nauczycielki doświadczały jakiegokolwiek rodzaju homofobii (niekoniecznie wyrażanej wprost w ich kierunku). Tylko jedna spośród moich rozmówczyń (R4 ujawniona nauczycielka z dużej miejscowości) powiedziała, że w ogóle nie spotkała się z dyskryminacją czy homofobią w szkole. Wszystkie inne wskazywały, że często słyszały homofobiczne żarty bądź oskarżające komentarze związane z paradami równości czy innymi wydarzeniami powiązanymi tematycznie z grupą osób LGBT. Część respondentek wskazywała także, że spotykała się z homofobicznymi wyzwiskami wypowiadanymi przez uczniów. Mówiły one m.in.:

Na pewno najgorszym wyzwiskiem w szkole było: idź ty pedale, idź ty cioto, albo jak ktoś chciał komuś przykrość zrobić, to dziewczyny wyzywał od lesbijek, myślę, że to było takie najgorsze wyzwisko, jakie można było wymyślić i obdarzyć nim dzieciaka (R8 nieujawniona nauczycielka pracująca w średniej miejscowości).

Niekiedy zaś - zwłaszcza młodsi - uczniowie akceptowali inność bardziej niż kadra pedagogów. Dzieci nie identyfikowały określonego stylu zachowania czy ubioru z orientacją seksualną, a także miały w sobie większą otwartość na różne sposoby zachowania. Dla kadry nauczycielskiej natomiast sposób bycia określany jako: „gejowski” był przyczynkiem do kpin (choć zazwyczaj niewpływających na bezpośrednie relacje z uczniem), na co wskazywały dwie spośród moich rozmówczyń:

Były komentarze, że jeden z uczniów wyglq̨da i zachowuje się jak pedał/gej. (R1 nauczycielka nieujawniona z dużej miejscowości).

Była taka jedna sytuacja, że nauczyciele komentowali jednego z uczniów, który był bardzo przegięty i mówili, że rośnie mały gej. Nie byli tym uczniem jakoś specjalnie zdegustowani, ale było to dla nich śmieszne. Natomiast dzieci lubiły go, nie dyskutowały na ten temat, nie wykluczały go. To było dla nich normalne, bo one były przyzwyczajone, że on zawsze się tak zachowuje (R2 nauczycielka nieujawniona z małej miejscowości). 
Jedna respondentka (R3 nauczycielka nieujawniona z krótkim stażem pracy, z dużego miasta), która pracowała w przedszkolu, potwierdzała, że z jej obserwacji wynika, że małe dzieci są obojętne wobec inności. Odniosła się ona raczej do zachowań osób dorosłych, które już na tym wczesnym etapie życia dziecka ściśle kontrolują wzorce zachowania i wykluczają określone zainteresowania niezgodne z rolami płciowymi. Z jej obserwacji wynika, iż bardzo wiele matek czy nauczycielek młodszych dzieci wpada w panikę bq̨dź reaguje niekiedy naprawdę bardzo agresywnie, gdy jakiś chłopiec chce, choćby przez chwilę pobawić się lalkq (R3 nauczycielka nieujawniona z krótkim stażem pracy, z dużego miasta).

Oczywiście wybór przez dziecka lalki jako obiektu do zabawy nie jest najczęściej powiązany z analizą własnej roli płciowej. Nieadekwatna reakcja nauczycielek i rodziców może być, według mojej respondentki, odbierana przez wrażliwe dziecko jako odrzucenie, niezależnie od tego, czy w przyszłości będzie ono hetero- czy też homoseksualne.

Jedna z moich rozmówczyń pracuje w szkole, gdzie zdecydowaną większość podopiecznych stanowią dziewczęta. Wskazała ona, że prawdopodobnie z tego względu w tej placówce można dostrzec częściej niż gdzieś indziej związki homoseksualne między uczennicami. Nie zmienia to jednak faktu, że zarówno sami uczniowie, jak i dyrekcja szkoły wykorzystują homofobiczne argumenty dla dyskryminacji mniejszości seksualnych. Uczennice domyślające się homoseksualnej orientacji jednej z nauczycielek wykorzystywały swe domniemania, by uzyskać władzę w klasie i dokuczyć nauczycielce, a opinię kierownictwa tej placówki respondentka określiła w takich słowach:

Dyrektor niegdyś powiedział w rozmowie quasi- koleżeńskiej, że uważa się za osobę wyrozumiałq i otwartq, ale lesbijki by nie zatrudnił (R6 nieujawniona nauczycielka z małego miasta).

Rozmówczyni ta w dalszej części rozmowy zauważyła, że z pewnością kierownictwo jej placówki zdaje sobie sprawę, że nie można nikogo zwolnić ze względu na orientację seksualną, jednak analizując wcześniejsze wypowiedzi dyrekcji, wnioskuje ona, że ujawnienie jej orientacji doprowadziłoby do zwolnienia jej pod innym pretekstem lub stworzenia atmosfery, w której sama zrezygnowałaby z pracy.

Tylko jedna spośród moich respondentek (ta która doświadczyła całkowitej akceptacji wśród grona nauczycielskiego swojej szkoły) nie obawiała się atmosfery szykan i wykluczenia, która mogłaby być efektem ujawnienia własnej orientacji seksualnej czy stylu życia. Większość kobiet podawała wiele argumentów na 
rzecz tezy, iż ich obawy były uzasadnione. Wskazywały, że nie trzeba było nawet być osobą homoseksualną, wystarczyło być podejrzewanym o mniejszościową orientację, czy też innego typu inność, by doświadczać ostracyzmu i obmów. Jedna z rozmówczyń wskazywała:

To było takie toksyczne środowisko, że jak ktoś tam nie był akceptowany, bo nie wiem, ktoś za dużo mówił, za mało mówił, źle mówił albo trzymał się nie z tymi, to potrafiono nasłać na niego jakqú kontrolę na przykład z kuratorium, zupełnie bezpodstawnie (R8 była nauczycielka ze wsi).

Inna kobieta przywołała przykład wskazujący na to, co mogłoby się stać, gdyby grono pedagogiczne zaczęło podejrzewać ją o mniejszościową orientację:

U nas pracował kiedyś taki facet. Mimo że miał swojq rodzinę, to chodziły o nim takie niedwuznaczne komentarze, że woli chłopaków. Jak były jakieś wyjazdy nauczycielskie, to wszyscy się nabijali, że tylko nie z nim w pokoju, bo coś tam; choć tak naprawdę jak tak obiektywnie na to patrzę, to nie widzę żadnych takich jego zachowań, ale do tej pory niektórzy się śmiejq̨ do kolegów: „o będziesz z nim w pokoju”, to jest podszyte takim szyderstwem, takq kpinq, $\mathrm{z}$ uśmiechem, z pobłażaniem traktowane (R5 nauczycielka nieujawniona z miasta średniej wielkości).

Wiele spośród moich rozmówczyń czuło się urażone i dotknięte „żartami”, komentarzami czy docinkami dotyczącymi konkretnych osób homoseksualnych, czy też orientacji homoseksualnej, jednakże żadna spośród nieujawnionych w swojej szkole nauczycielek nie reagowała, słysząc takie słowa. Wszystkie przeżywały te momenty w milczeniu, przekonane, iż jakikolwiek komentarz zdradziłby, że są one osobiście zainteresowane tematem i plotki czy oszczerstwa mogłyby zacząć dotykać ich w bardziej osobisty sposób. Pomimo tego że wiele spośród nich chciałoby sprzeciwić się, zareagować na tego typu komentarze, blokowała je mniejszościowa pozycja i strach. Jedna z kobiet powiedziała nawet:

gdybym była heteroseksualna zareagowałabym, wtedy nic nie mogłoby mi grozić, bo nawet gdyby zaczęli mnie podejrzewać, to byłaby nieprawda (R2 nauczycielka nieujawniona pracująca w małym mieście). 


\section{WPŁYW MNIEJSZOŚCIOWEJ POZYCJI NA RELACJE Z PODOPIECZNYMI}

Kobiety, z którymi rozmawiałam, wskazywały, że obawiają się, że ich orientacja seksualna zostanie zinterpretowana przez grono pedagogiczne oraz rodziców podopiecznych jako dewiacja, która w ich przekonaniu powinna wykluczyć je z kontaktu z dziećmi czy młodzieżą. Niektóre spośród moich rozmówczyń wskazywały, że świadomość, iż homoseksualność jest wiązana stereotypowo z pedofilią, sprawiała, że obawiały się, że jakikolwiek przyjazny gest kierowany w stronę ucznia może zostać odebrany jako wyraz aktywności seksualnej. Jedna z moich rozmówczyń (R3 nauczycielka z krótkim stażem, z dużego miasta), która pracowała w przedszkolu, opowiadała, że w przypadkach, gdy musiała przebierać dziecko odwracała wzrok, od miejsc intymnych dziecka (choć to utrudniało jej czynności pielęgnacyjne), była jednak pełna obaw o możliwość posądzenia jej o pedofilię. Inna spośród moich respondentek wskazywała, że musi szczególnie się pilnować, bo z pewnością dyrekcja szkoły, która wie o jej orientacji, zwraca szczególną uwagę na to, czy przytula ona dzieci, unikała więc jakiegokolwiek kontaktu dotykowego. Kobiety te nie obawiały się tego typu posądzeń ze względu na bezpośrednie komentarze, jakie uzyskały ze strony przełożonych czy innych nauczycieli, jednakże niemal wszystkie nauczycielki (prócz dwóch, które ujawniły swoją orientację) wskazywały, że właściwie istotą homofobicznych tekstów czy żartów słyszanych w pokoju nauczycielskim było założenie, iż homoseksualność jest związana z zaburzeniem preferencji seksualnych, które mogą się różnie przejawiać. Jak wyraziła to jedna z moich rozmówczyń:

Ludziom wydaje się, że bycie lesbijkq to coś bardzo kontrowersyjnego. Bałam się, że rodzice dzieci pomyślq tak: jest lesbijkq - to znaczy, że jest zboczona - to znaczy, że jest z jakimiś dewiacjami i pewnie molestuje dzieci (R3 nauczycielka z krótkim stażem, z dużego miasta).

Tego typu ciąg myślowy (pozbawiony oczywiście potwierdzenia ze strony jakichkolwiek badań naukowych) jest powtarzany w części dyskursów katolickich. Moje rozmówczynie, spośród których tylko jedna uczyła w szkole katolickiej, wskazywały, że w ich szkole niezwykle duże znaczenie miała postać księdza, który wygłaszał obecne w części mediów katolickich przekonania o tym, że homoseksualność jest chorobą i dewiacją. Jedna z respondentek powiedziała:

Ksiq̨dz miał w naszej szkole dużq władzę. To, co mówił, było święte. Przyjaźnił się z dyrektorkq, często się odwiedzali, on też sponsorował wyjazdy dzieciakom. 
Był dobrym wujkiem i dobrze żył z ludźmi, z tego względu miał dużq̨ władzę. Tak zresztq jest często w szkołach wiejskich czy małomiasteczkowych. Sojusz między parafiq a szkoła jest bardzo silny (R8 była nauczycielka, pracowała na wsi).

Także inne respondentki wskazywały na to, że silna pozycja księdza katechety w ich szkole sprawiała, że kobiety o wiele bardziej obawiały się, że w momencie ujawnienia własnej orientacji mogłyby doznać szykan. W szkołach małomiasteczkowych i wiejskich grono pedagogiczne milcząco aprobuje poglądy wyrażane przez przedstawiciela kościoła:

Nasza szkoła nie jest katolicka, ale jest bardzo prokościelna. Jak ktoś ma inne zdanie, to się tego głośno nie mówi (R5 nauczycielka nieujawniona pracująca w średniej wielkości mieście).

Jednakże jedyna respondentka pracująca w szkole katolickiej stwierdziła, że niezależnie od tego, czy szkoła jest katolicka, czy nie, ujawnienie się nauczycielki homoseksualnej będzie rodziło podejrzenia o pedofilię, a żaden dyrektor nie chce zmagać się z tego typu oskarżeniami (nawet jeśli są zupełnie niesłuszne) (R1 nieujawniona nauczycielka z dużego miasta).

Pomimo tych wszystkich trudności sprawiających, że moje rozmówczynie nie reagowały w żaden sposób, wtedy gdy słyszały homofobiczne żarty czy docinki; wszystkie starały się ukształtować w swoich wychowankach postawę tolerancji i otwartości, akceptacji wobec inności. W ten sposób dawały wsparcie wykluczanym uczniom. To był także ich sposób innego przeciwstawiania się obecnej w szkołach homofobii. Zjawisko takiego cichego oporu opisuje również rozmówczyni Ann Hardie - Lilly, dziś już dorosła uczennica nieheteronormatywnej nauczycielki. Jej wychowawczyni nigdy nie ujawniła swojej orientacji, ale swoim sposobem bycia i wewnętrzną siłą, a także cechami charakteru czy metodami, jakimi prowadziła zajęcia, dawała dziewczynce, która odczuwała swoją odmienność, ogromne wsparcie.

Lilly stwierdziła:

To interesujq̨ce, to powinno być napisane w tym artykule, że nauczycielka może wywierać wpływ, pomagać albo zmieniać wzorce dyskryminacji, nawet jeśli nie dokona „coming out-u”. Wystarczy, by była sobq. To jej cicha siła, to zasiewanie ziaren wiedzy o zróżnicowanym świecie (Hardie, 2012, s. 278). 
Taką postawę „,ichej siły” Michel de Certeau nazywa taktyką wykorzystywaną przez słabszego, grupę mniejszościową czy uciskaną (2008, s. 36-38). Wskazuje on na to, że pomimo wykluczenia czy gorszej pozycji jednostka bądź mała grupa może niemal zawsze odnaleźć możliwość uczynienia drobnego wyłomu w systemie, wykorzystując faktycznie jego luki. Nie dokonuje się wtedy rewolucja, ale jednak jednostka może odnaleźć swoją niszę czy możliwość wyrażania się, wolności, kreatywności. Być może ta taktyczna siła daje moim respondentkom możliwość ciągłej pracy w środowisku, w którym nie mogą pokazać swojego prawdziwego oblicza. W niektórych sytuacjach, w relacjach z uczniami mogą zawalczyć o to, co dla nich jest naprawdę istotne. Jedna z moich rozmówczyń użyła w stosunku do swoich działań antydyskryminacyjnych, które podejmowała w szkole, dokładnie tej samej metafory, która wystąpiła w wypowiedzi wspominanej Lilly: starałam się zaszczepić w nich to ziarenko, by ono kiełkowało (Hardie, 2012, s. 278). Nauczycielka, która po 10 latach zrezygnowała z pracy w szkole, mówi:

Przez długie lata byłam wychowawcq klasy, więc jak tylko była taka możliwość, to starałam się z tymi dzieciakami rozmawiać, na lekcji, gdzieś na wycieczce, tak przy okazji. Jeśli chodzi o osoby nieheteronormatywne, to przyznam, że wprost nie omawiałam tego tematu generalnie, myślę, że gdybym wprost opowiadała, to byłoby źle, ale kiedyś zrobiłam taki temat na godzinie wychowawczej: inność to nie znaczy wrogość czy coś takiego i tam też wplotłam ten temat jako jeden z wielu (R8 była nauczycielka, nieujawniona, pracująca na wsi).

Respondentka nie uwypuklała tematyki homofobii, ale zajmując się wieloma wykluczeniami i tematyką akceptacji wobec inności, dała faktycznie wsparcie wszystkim tym uczniom i uczennicom, którzy mogli się czuć odrzuceni z wielu różnych powodów. Inne kobiety także zwracały uwagę na to, że ze względu na to, że są w mniejszości cechuje je większa wrażliwość na los innych mniejszości. Mówiły:

Myślę, że odkq̨d zrobiłam porzq̨dek z tq sferq, jestem bardziej otwarta i tolerancyjna dla ludzi (R5 nauczycielka nieujawniona, ze średniej miejscowości).

Na moich lekcjach częściej pojawiajq się tematy równościowe i jestem bardziej przekonywujq̨ca w tych kwestiach. Przy różnych okazjach, nie mówię o sobie, ale poruszam tematy dotyczq̨e sprawiedliwości (R7 ujawniona nauczycielka $\mathrm{z}$ dużego miasta). 
Chciałabym doświadczyć pełnej tolerancji, więc ja też jestem tolerancyjna na słabości innych i kwestie mniejszościowe (R2 nauczycielka nieujawniona z małego miasta).

Bardziej dostrzegam problemy uczniów. Moja postawa jest mniej krytykująca, a bardziej akceptujq̨ca, dlaczego częściej mi się zwierzajq (R6 nauczycielka pracująca na wsi, nieujawniona).

Wszystkie te wypowiedzi świadczą o tym, że pomimo wielu problemów wynikających z poczucia wykluczenia respondentki są przekonane o tym, że ich mniejszościowa pozycja nie tylko nie przeszkadza im w pełnieniu roli nauczyciela, ale wręcz pomaga im być lepszymi wychowawcami, bardziej wyczulonymi na potrzeby uczniów i skupiającymi wokół siebie osoby doświadczające trudności w bardzo różnych obszarach życia. Mniejszościowa pozycja natomiast bardzo przeszkadza moim respondentkom odnaleźć się w ramach systemu szkoły i relacji z dyrekcją, rodzicami i współpracownikami.

\section{WNIOSKI}

Jakościowe badania metodą wywiadu pogłębionego, uzupełnione analizą literatury, a także wspomagającym źródłem, jakim było forum internetowe, na którym wypowiadały się osoby związane z tym tematem, wykazują, że nieheteronormatywne nauczycielki najczęściej nie ujawniają swojej orientacji w miejscu pracy, utrzymując w tajemnicy wiele aspektów swojego życia prywatnego. Spośród ośmiu respondentek jedynie jedna ujawniła swoją orientację w pierwszych tygodniach pracy, druga kobieta ujawniła ją po kilku latach w wyniku doświadczanych szykan, a pozostałe kobiety ujawniły informacje o swoim życiu prywatnym jedynie jednej lub dwóm osobom. Dwie respondentki nikomu nie powiedziały o swojej sytuacji. Ukrywanie wielu faktów z życia osobistego sprawia, że kobiety czują się wykluczone i stawiane w kłopotliwych sytuacjach (związanych z wyszukiwaniem im partnerów). Obawiają się one jednak ujawnić swoją mniejszościową pozycję ze względu na lęk przed przemocą psychiczną i głębszą izolacją, a także oskarżeniami, w których padałyby bardzo poważne zarzuty (np. przemocy seksualnej wobec dzieci). Wiele kobiet bało się utraty pracy, ale ostatecznie dwie respondentki same zrezygnowały z pracy w oświacie, nie mogąc wytrzymać sytuacji, w jakiej się znalazły. Wiele respondentek wskazywało, że oprócz samego zwolnienia obawiały się przemocy, jaka by temu towarzyszyła. Ze względu na to, że więk- 
szość respondentek nie ujawniała swojej orientacji, doświadczały one homofobii wyrażanej niewprost, ale poprzez powtarzane homofobiczne żarty i oskarżenia wobec osób o mniejszościowej orientacji. Obawa przed posądzeniem o pedofilię sprawiała, że kobiety nie ujawniały niejednokrotnie swojej wylewności czy emocjonalnego ciepła, jednakże wszystkim im bardzo zależało na tym, by silnie kształtować w uczniach postawę otwartości, wzajemnego wsparcia i akceptacji dla inności oraz wagę sprawiedliwego traktowania wszystkich ludzi. W stosunku do uczniów kobiety walecznie sprzeciwiały się przemocy i dawały wsparcie osobom wykluczanym z różnych powodów, były też w ich własnym przekonaniu bardziej rozumiejące i empatyczne, nastawione na słuchanie, a nie na ocenianie i krytykę czyjegoś zachowania.

\section{Literatura:}

de Certeau, M. (2008). Wynaleźć codzienność. Sztuki działania. Kraków: Wydawnictwo Uniwersytetu Jagiellońskiego.

Chińcz, M. (2006). Lesbijki w życiu społeczno-politycznym. Płock: Fundacja Lorga.

Hardie, A. (2012). Lesbian teacher and students: issues and dilemmas of being 'out'in primary school. Sex education, 3, s. 273-282.

Juul, T. (1996). Joining gay and lesbian teacher organization, a study of members and non-members. American Educational Research Organization, April.

Klaus, W., Winiarska, A. (2011). Dyskryminacja i nierówne traktowanie jako zjawisko społeczno-kulturowe. Studia BAS, 2 (26), s. 9-40.

Kochanowski, J. (2007). Poza horyzont heteronormatywności. Ruchy społeczne gejów i lesbijek. Societas/Communitas, 2, s. 133-156.

Konarzewska, M. (2010). Jestem nauczycielką i jestem lesbijką. Gazeta Wyborcza. Pobrane z: http://wyborcza.pl/1,76842,8034607,Jestem_nauczycielka_i_jestem_lesbijka.html.

Kotowska, M. (red.), (2011). Rzeczywistość osób homo- i biseksualnych w Polsce: geje i lesbijki w Polsce. Warszawa: Stowarzyszenie Lambda.

Lizurej, M. (2004). Lesbijki? Przecież nas nie ma. W: B. Warkocki, Z. Sypniewski (red.), Homofobia po polsku (s. 165-184). Warszawa: Sic!

Marciniak, J. (2011). Mobbing, dyskryminacja, molestowanie. Zasady przeciwdziałania. Warszawa: Wolters Kluwer.

Maruszewski, S., Molisiak A., Pruss, A. (red.), (2003). Przełamać milczenie: łamanie praw człowieka ze względu na orientację seksualną. Gdańsk: Amnesty International Polska.

Mizielińska, J. (2006). Płeć, ciało, seksualność. Od feminizmu do teorii queer. Kraków: Universitas.

Mizielińska, J., Abramowicz M., Stasińska A., http://rodzinyzwyboru.pl/wp-content/ uploads/2014/10/Raport_Rodziny-z-wyboru-w-Polsce.-\%C5\%BBycie-rodzinneos\%C3\%B3b-nieheteroseksualnych.pdf. 
Moreau, M.P. (red.), (2014). Inequalities in teacher profession. A Global perspective. York: Palgrave Macmillan.

Nickeson, S. (1980). A comparison of gay and heterosexual teachers on professional and personal dimensions. Dissertation presented to the graduated council of the University of Florida. University of Florida (dysertacja niepublikowana).

Radziszewska, E. (2010). Misja Elżbieta. Gość Niedzielny. Pobrane z: http://gosc.pl/ doc/809338.Misja-Elzbieta.

Rudoe, N. (2010). Lesbian teachers', identity, power and public/private boundary. Sex Education, 1, s. 23-36.

Sparkes, A.C. (1994). Self, silence and invisibility as a beginning a teacher: a self history of lesbian experience. British Journal of Sociology and Education, 1 (15), s. 93-118.

Warkocki, B. (2013). Różowy język. Literatura i polityka kultury na początku wieku. Warszawa: Wydawnictwo Krytyki Politycznej. 